\title{
Seasonal and Latitudinal Variations in Circadian Rhythms of Red-Backed Vole
}

\author{
LUCIUS L. STEBBINS ${ }^{1}$
}

\begin{abstract}
Circadian rhythms of two allopatric species, Clethrionomys gapperi and $C$. rutilus were studied near their common border at Heart Lake, Northwest Territories, Canada, in winter and spring of 1965-1966. Circadian rhythms of $C$. gapperi were also studied at Edmonton, Alberta, in the winter and spring of 19641965. Activity was measured by recording passages through a door in cages exposed to normal meteorological conditions of the forest floor. Daily peaks of activity of each species were of longer duration and higher amplitude in spring than in winter. C. rutilus was polyphasic in winter, nocturnal in spring. $C$. gapperi at Heart Lake was nocturnal in winter but had peaks of activity persisting from dusk each evening to noon of the following day. C. gapperi at Edmonton was diurnal in all seasons.
\end{abstract}

RÉSUMÉ. Variations saisonnières et latitudinales dans les rythmes circadiens chez le Campagnol à dos roux. Durant l'hiver et le printemps 1965-1966, l'auteur a étudié les rythmes circadiens de deux espèces allopatriques, Clethrionomys gapperi et $C$. rutilus, près de leur frontière commune, au lac Heart, Territoires du Nord-Ouest, Canada, il a aussi observé les rythmes circadiens de C. gapperi à Edmonton, Alberta, pendant l'hiver et le printemps 1964-1965. Il a mesuré l'activité en enregistrant les passages à travers une porte dans des cages exposées aux conditions météorologiques normales du sous-bois forestier. Les sommets quotidiens d'activité de chaque espèce sont de plus longue durée et de plus grande amplitude au printemps qu'en hiver. C. rutilus est polyphasique en hiver et nocturne au printemps. A Heart Lake, $C$. gapperi est nocturne en hiver, mais avec des sommets d'activité persistant du crépuscule jusqu'au milieu du jour suivant. A Edmonton, $C$. gapperi est diurne en toutes saisons.

РЕЗЮМЕ. Сезонные и ииротные изменения суточных ритмов активности красной полевки. В зимний и весенний периоды 1965-1966 тг. изучались суточные ритмы активности двух аллопатрических видов (Clethrionomys gapperi и С. rutilus) в районе их совместного распространения (озеро Харт, СевероЗападные Территории, Канада). Суточные ритмы активности С. gapperi также изучались в окрестностях Эдмонтона, Альберта, в зимний и весенний периоды 1964-1965 гг. Активность измерялась регистрацией прохождения полёвок черев дверцу клетки, выставленной в лесу при обычных метеорологических условиях. Ежедневные пики активности обоих видов были более продолжительынми и интенсивными в весенний период, чем в зимний. Активность C. rutilus проявлялась весной в ночное время, в то время как зимой она не вависела от времени суток. С. gapperi на озере Харт вели ночной образ жизни, но пики активности продолжались ежедневно от вечерних сумерек до полудня следующего дня. Активность C. gapperi в раноон Эдмонтона отмечалась в дневное время независимо от времени года.

\section{INTRODUCTION}

Circadian rhythms of $C$. gapperi were studied from December 1964, to 30 June 1965 , at Edmonton, Alberta $\left(53^{\circ} 33^{\prime} \mathrm{N} ., 113^{\circ} 28^{\prime} \mathrm{W}\right.$.) Circadian rhythms of $C$. gapperi and $C$. rutilus were studied during December 1965, and May and June 1966 , at the Heart Lake Biological Station at the University of Alberta $\left(60^{\circ} 45^{\prime} \mathrm{N}\right.$., $116^{\circ} 40^{\prime}$ W.), 50 miles west of Hay River, Northwest Territories. Subnivean temperatures and photoperiod were also recorded.

${ }^{1}$ Department of Biology, University of Lethbridge, Alberta, Canada. 
This study was made to test whether circadian rhythm of Clethrionomys gapperi and $C$. rutilus, two allopatric species which meet along a narrow zone of contact at about $60^{\circ} \mathrm{N}$. between Hudson Bay and the Pacific Ocean, are similar and how they vary by season and latitude.

For a review of relationships between circadian rhythms and environmental fluctuations see Stebbins (1968).

\section{METHODS AND MATERIALS}

\section{Activity}

At Edmonton, circadian rhythms of 3 male and 3 female $C$. gapperi trapped locally prior to the experiments were studied; at Heart Lake, 2 males and 2 females of each species of Clethrionomys trapped near the experimental area were studied.

Activity cages of $1 / 2$-inch $(12 \mathrm{~mm}$.) wire mesh, measuring $30 \times 30 \times 60 \mathrm{~cm}$. were placed on the forest floor in quiet, natural areas. Voles were housed one to a cage and were provided with nest boxes $8 \times 8 \times 16 \mathrm{~cm}$. which were insulated on all surfaces by $2.5 \mathrm{~cm}$. of styrofoam. Terylene fibre was provided for nesting material. Sunflower seeds and Purina laboratory mouse food were ad libitum. Cages and nest boxes were cleaned, and fresh food added, every 2 weeks. In winter, cages were partially or completely filled with snow, and the animals had to tunnel to find food or exercise.

Swinging doors in small entrance tunnels operated mercury switches in adjacent boxes. The switches activated a 20-pen Esterline Angus event recorder in a nearby trailer. Movements in and out of the nest boxes were used as an index of total activity. For analysis total number of passages across the switch were counted for each hour of the day and the hourly values were averaged for each 2-week test period.

\section{Weather}

Aerial and ground surface temperatures were recorded continuously with a Yellow Springs Instrument Sequencing Telethermometer (Model 80) and recorder (Model 47) placed near the activity experiments. At Edmonton, ground surface temperatures were recorded about $2 \mathrm{~cm}$. under the surface of the leaf litter; at Heart Lake about $2 \mathrm{~cm}$. under the surface of the lichen cover.

Photoperiod was recorded continuously at both latitudes using Rustrak recorders and Silicon solar cells combined into field instruments. The sun meters were placed $60 \mathrm{~cm}$. above the forest floor, adjacent to the activity cages.

\section{RESULTS}

\section{Weather}

Winter at Edmonton was characterized by a frequent alternation of periods of relative cold and thawing. The coldest subnivean temperature $\left(-11^{\circ} \mathrm{C}\right.$.) was recorded in early January 1965 . Subnivean temperatures rose above freezing in mid-January 1965 , and remained between $-6^{\circ} \mathrm{C}$. and $+1^{\circ} \mathrm{C}$. until loss of snow cover in early April. 


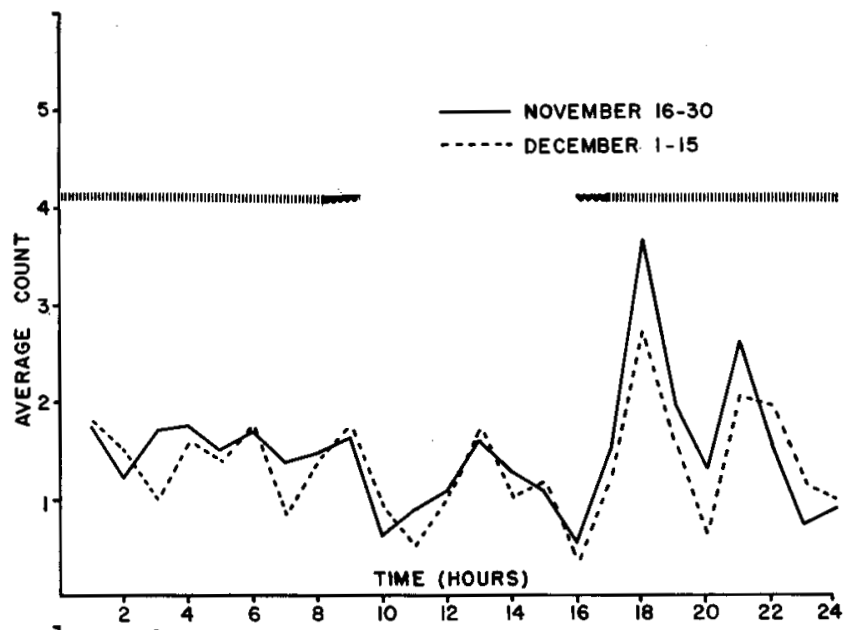

FIG. 1. Activity of $C$. gapperi from Heart Lake as tested at Heart Lake. Two males and two females housed individually were tested. "Average Count" is the average number of times the gates at the entrance of the nest boxes were crossed by the test animals for each time interval. Time is given with hour 0100 through hour 2400 abbreviated to hour 1 through hour 24 . Periods of darkness are indicated by vertical stippled lines across the top of the graph. Range of variation in photo-

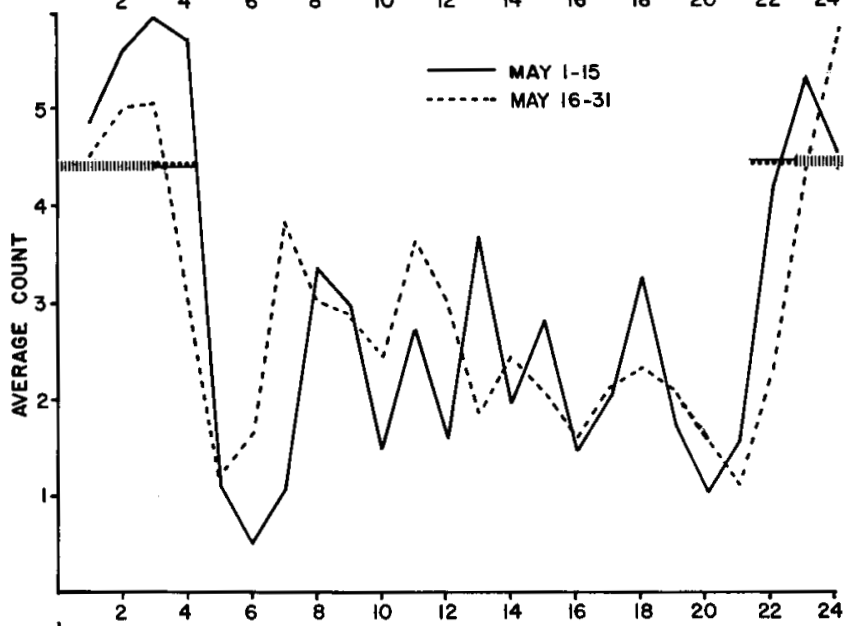
period is indicated by the short line with loops.

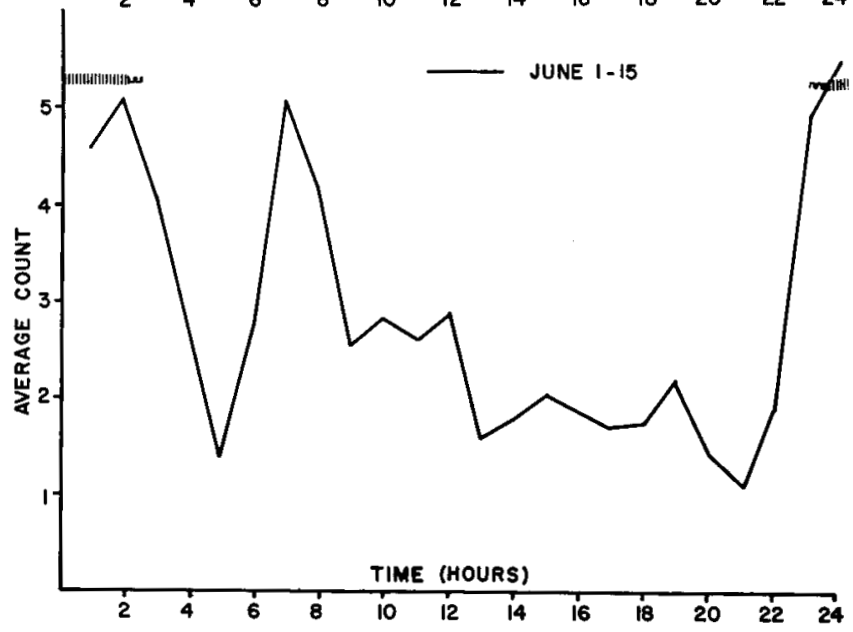


Subnivean temperatures at Heart Lake were much colder. Subnivean temperatures did not rise above $-5^{\circ} \mathrm{C}$. between 18 November 1965 and 26 March 1966. Between late December 1965 and 20 February 1966, subnivean temperatures were between $-9^{\circ} \mathrm{C}$. and $-13^{\circ} \mathrm{C}$. For details see Stebbins (1968) or Fuller, Stebbins and Dyke (1969).

Photoperiod is indicated on each of the activity graphs (Figs. 1-4).

\section{Activity}

C. gapperi was nocturnal at Heart Lake during November and December 1965 , and May and June 1966 (Fig. 1). A bimodal peak of activity occurred shortly after dark in winter and persisted through the first 6 hours of darkness. A similar pattern occurred in May but the general level of activity was higher. The distribution of activity during the peak was still bimodal in June but it persisted through the first 6 to 8 hours of daylight the following morning. Level of activity was generally much higher in spring than winter.

C. gapperi captured and tested at Edmonton had definite early morning peaks of activity in early winter, spring, and early summer (Figs. 2 and 3). In November, December, and January a peak of activity occurred in the early daylight hours. The morning peak of activity was inconsistent in January and February, a time when the cages were entirely filled and covered with snow.

A relatively definite morning peak of activity returned in the early daylight hours of March, April, May, and June.


FIG. 2. Activity of C. gapperi from Edmonton as tested between November 16, 1964, and February 28, 1965, at Edmonton. Three males and three females housed individually were tested. Refer to the legend of Fig. 1 for details. 
In late fall and winter, the level of activity was generally lower than in spring. Activity for all daylight hours increased markedly in early May, and continued to increase through the end of June (Fig. 3).

Circadian rhythms of $C$. rutilus also changed seasonally. In winter the distribution of activity of $C$. rutilus appeared to be without an obvious peak (Fig. 4), a pattern also suggested by Pruitt (1959). In spring, a definite circadian rhythm with a nocturnal pattern of activity occurred. The nocturnal peak of activity was of lower amplitude in the first 2 weeks of May, but increased markedly during late May. In early June the daily peak of activity began about an hour before the onset of darkness and persisted into the first hour of daylight the following morning.

\section{DISCUSSION}

Obvious seasonal differences in the circadian rhythms of $C$. gapperi and $C$. rutilus involve the duration, phase, modality, and amplitude of their daily peaks of activity. Discussion will be restricted to changes in phase, duration, and amplitude. Modality will be discussed in a separate paper.

It has been suggested that circadian rhythms form an important basis for relationships between a species and its environment and that some of the more important factors favouring selection of circadian rhythms involve competition, escape, reproduction, and feeding (Johnson 1926; Park 1935; Hamilton 1937;
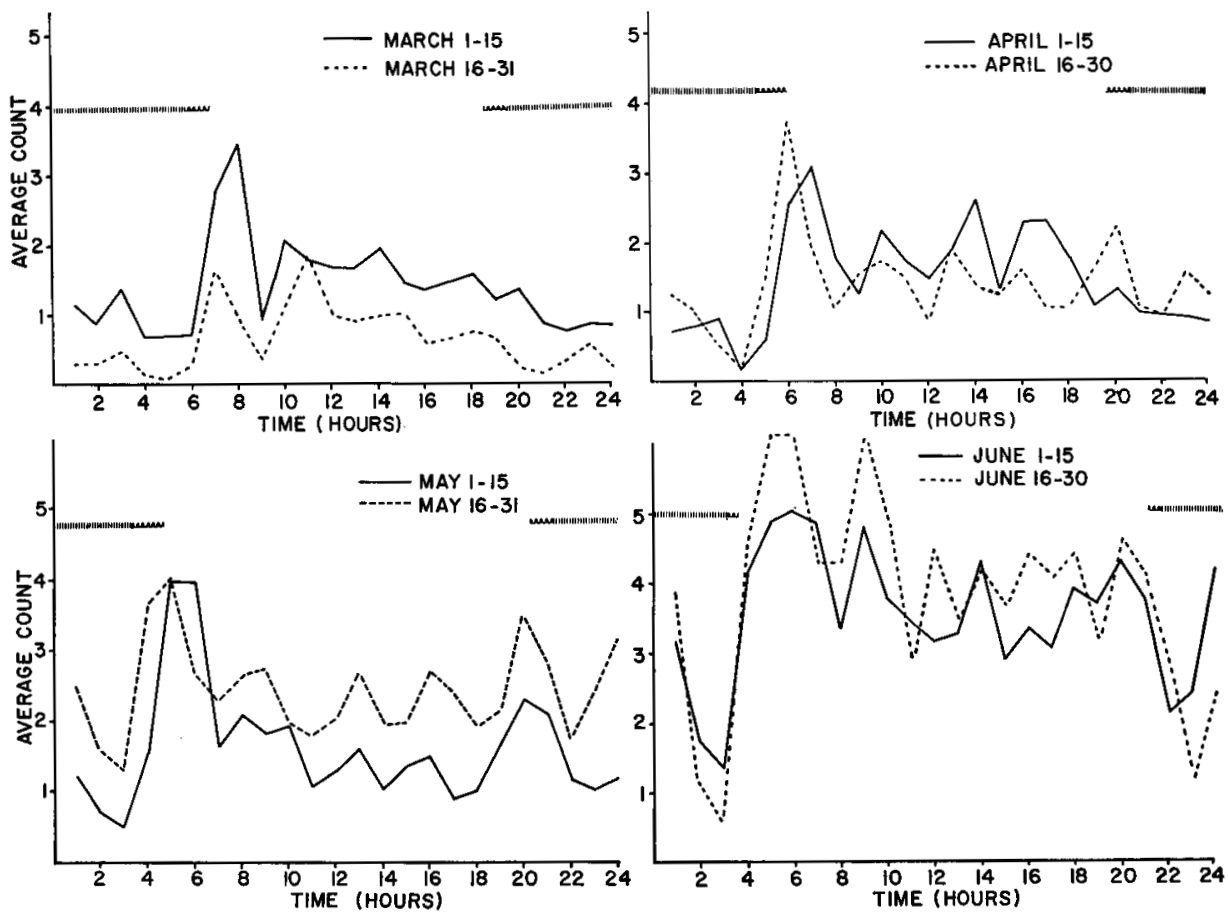

FIG. 3. Activity of C. gapperi from Edmonton as tested between March 1, and June 30, 1965, at Edmonton. Three males and three females housed individually were tested. Refer to the legend of Fig. 1 for details. 


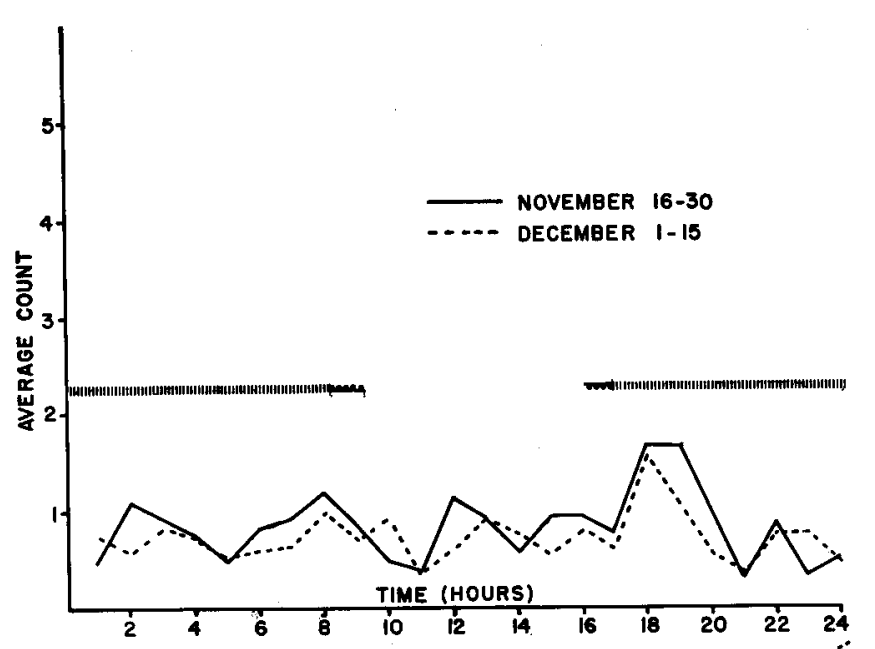

FIG. 4. Activity of C. rutilus from Heart Lake as tested at Heart Lake. Two males and two females housed individually were tested. Refer to the legend of Fig. 1 for details.
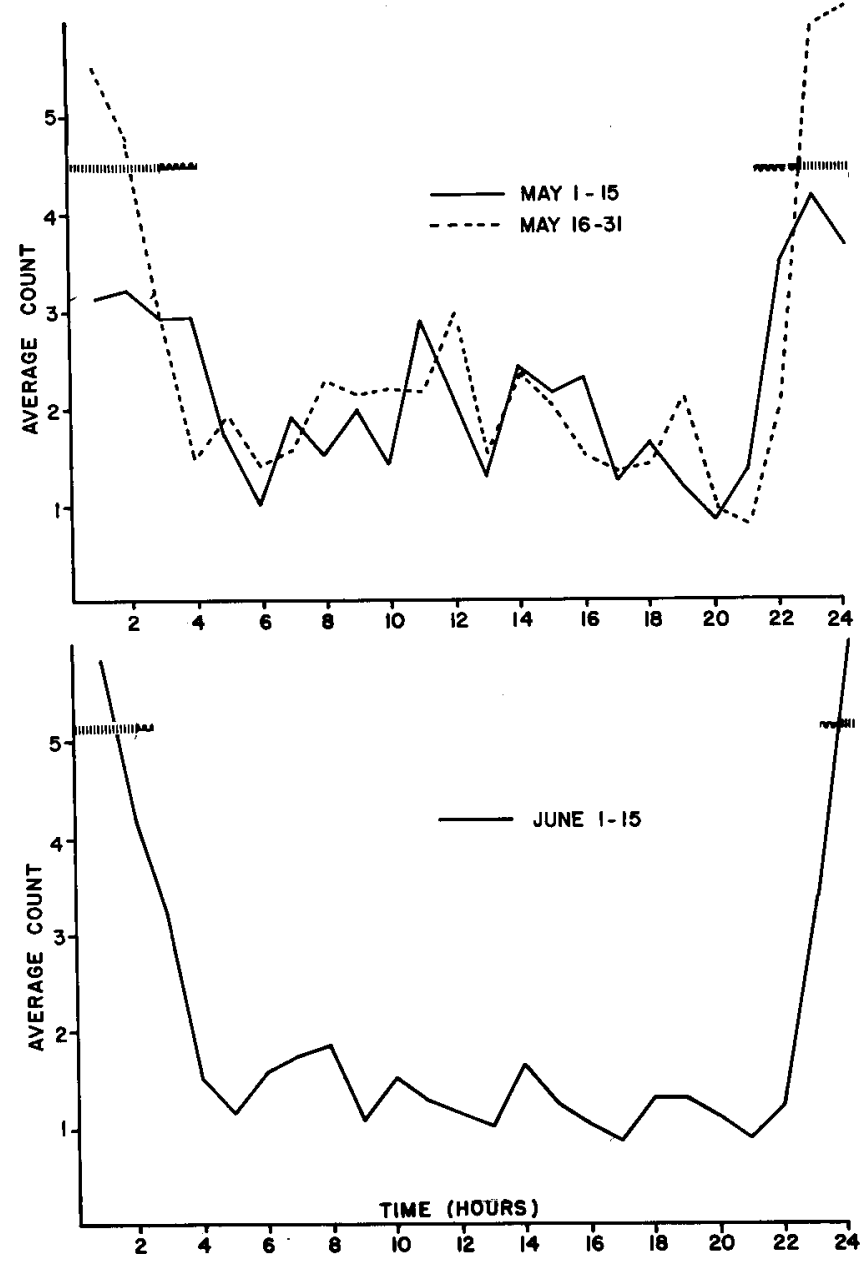
Armstrong 1954; Miller 1955; Cloudsley-Thompson 1960; Kikawa 1964). This suggests that an animal would gain an adaptive advantage by conducting its reproductive, territorial, nesting, or foraging behaviour within a certain time period each day, and that seasonal changes in behaviour could be directly related to seasonal changes in circadian rhythms.

Proof of such an hypothesis would be difficult, as it would depend upon long term behavioural studies done under natural conditions. However there is circumstantial evidence that the seasonal changes in circadian rhythms observed in this study coincided with seasonal changes in reproductive, territorial, nesting, and foraging behaviour in the natural population.

In winter, when growth rate was slow and no reproduction occurred (Stebbins 1968; Fuller et al. 1969), amplitude and duration of daily peaks of activity of caged animals were low.

In natural conditions the amount of foraging may decrease in winter. I saw few tracks on the surface of the snow after snow reached a depth of about 15 to $20 \mathrm{~cm}$., an observation previously reported by Pruitt (1957). A constant snow cover and lack of botanical productivity would physically limit effectiveness of foraging in winter, and evidence exists that $C$. rutilus and other species of Clethrionomys in the Soviet taiga store their food supply in caches sufficient to last all winter (Koshkina 1957).

Territoriality may be of less importance in winter in natural conditions; dispersion of young would not be occurring. Rather than change nesting sites frequently, voles would probably remain near their winter food stores. This would depend on the percentage of their food which is stored for winter, as yet an unknown factor, though in captivity voles tended to store all of their seeds. Groups of voles, in nature, probably families, seemed to live in the same nest. I commonly captured several voles, up to 7 , at one nest under the snow.

In spring, with onset of reproduction and loss of snow cover, circadian rhythms of captive animals were altered. Increased activity has been associated with reproduction in several species (Wald and Jackson 1944; Folk 1966) and with increased foraging associated with loss of snow cover in Clethrionomys spp. (Koshkina 1957).

However, a general paucity of information concerning occurrence and distribution of different behaviour patterns relative to different stages of circadian rhythms remains. Until information is collected on daily and seasonal changes in territorial, nesting, foraging, and reproductive behaviour, development and support of hypotheses as to causal relationships between such behaviour and circadian rhythms will be difficult.

Increased energy demand for thermoregulation in winter may also alter activity (Kendeigh 1949; Davis 1955; McNab 1963; Kontogiannis 1968; West 1968). I have previously mentioned this possibility for Peromyscus maniculatus (Stebbins 1971). The same arguments seem pertinent for Clethrionomys spp.

Reasons for latitudinal differences in phase of the circadian rhythms of $C$. gapperi remain open questions, but a response to photoperiod by $C$. gapperi could be a factor. With a snow cover during 6 months of the year and short days characterized by dim or no light during winter months, $C$. gapperi at the northern 
periphery of its range may have become more nocturnal as an aid to winter survival. Though $C$. gapperi were active throughout the winter, trapping results, and observations of tracks and tunnels in the snow indicated most of their activity was restricted to the subnivean environment. After early December it was rare to see vole tracks on the snow surface. Though small tunnels commonly opened to the surface, the voles seldom ventured onto the surface after the first month or so of snow cover.

Finally, possible relationships between allopatry and the circadian rhythms of these 2 species should be mentioned. The daily peaks of activity of $C$. gapperi and $C$. rutilus were quite similar along their zone of contact. If the majority of foraging, nesting, territorial and reproductive behaviour occurs during the time of peak activity, survival and distribution of each species may be affected by its interactions with the other during the daily peak of activity. Because these species seem to be mutually exclusive ecological equivalents, such a possibility should be further explored.

\section{ACKNOWLEDGEMENT}

I wish to acknowledge the receipt of supporting funds from the National Research Council of Canada and the University of Alberta. I thank Dr. William A. Fuller and Dr. G. Edgar Folk for their professional and personal encouragement during the project.

\section{REFERENCES}

ARMSTRONG, E. A. 1954. The behaviour of birds in continuous daylight. Ibis, 96: 1-30.

CLOUdSLeY-THOMPSON, J. L. 1960. Adaptive function of circadian rhythms. Proceedings of the Cold Springs Harbor Symposium on Quantitative Biology, 25: 345-57.

DAVIS, E. H., SR. 1955 . Seasonal changes in the energy balance of the English Sparrow. Auk, 72: $385-411$.

FOLK, G. E., JR. 1966. Introduction to environmental physiology. Philadelphia: Lea and Febiger. 308 pp.

FULLER, W. A., L. L. STEBBINS and G. R. DYKE. 1969. Overwintering of small mammals near Great Slave Lake northern Canada, in 1965-1966, and 1966-1967. Arctic, 22: 34-55.

hAMILTON, w. J., JR. 1937. Activity and home range of the field mouse, Microtus pennsylvanicus pennsylvanicus. Ecology, 18: 255-63.

JoHNSON, M. s. 1926. Activity and distribution of certain wild mice in relation to biotic communities. Journal of Mammalogy, 7: 245-77.

KENDEIGH, C. S. 1949. Effect of temperature and season on energy resources of the English Sparrow. $A u k, 66(2):$ 113-27.

KIKAWA, J. 1964. Movement, activity, and distribution of the small rodents Clethrionomys glareolus and Apodemus sylvaticus in woodland. Journal of Animal Ecology, 33: 259-95.

KONTOGIANNIS, J. E. 1968. Effect of temperature and exercise on energy intake and body weight of the White-Throated Sparrow Zontrichia albiiollis. Physiological Zoology. 41(1): 54-64.

xoshkiNA, T. v. 1957. Comparative ecology of the red-backed voles in the northern taiga. Materials about rodents, No. 5, Fauna and ecology of rodents. Moscow Society of Naturalists, 3-65. 
MCNAB, B. K. 1963. A model of the energy budget of a wild mouse. Ecology. 44: 521-32.

MILLER, R. S. 1955. Activity rhythms in the wood mouse, Apodemus sylvaticus, and the bank vole, Clethrionomys glareolus. Proceedings of the Zoological Society of London, 125: 505-19.

PARK, 0. 1935. Studies in nocturnal ecology, III. Ecology, 16: 152.

PALMGReN, P. 1949. On the diurnal rhythms of activity and rest in birds. Ibis, 91: 561-76.

PRUITT, W. O. JR. 1957. Observations of the bioclimatic of some taiga mammals. Arctic, 10: $130-38$. 40(1): 139-43.

STEBBINS, L. L. 1968. Seasonal changes in the circadian rhythms of some small northern rodents. Unpublished Ph.D. thesis, University of Alberta.

1971. Seasonal variations in circadian rhythms of deer mice in northwestern Canada. Arctic, 24: 124-31.

WALD, G. and B. JACKSON. 1944. Activity and nutritional deprivation. Proceedings of the National Academy of Science, 30: 255-63.

WEST, G. C. 1968. Bionergetics of captive Willow Ptarmigan under natural conditions. Ecology, 49(6): 1035-45. 